\title{
Do the benefits of exercise in indoor and outdoor environments during the COVID-19 pandemic outweigh the risks of infection?
}

\author{
Fábio Hech Dominski ${ }^{1,3} \odot \cdot$ Ricardo Brandt ${ }^{2} \odot$
}

Received: 22 April 2020 / Accepted: 4 July 2020 / Published online: 17 July 2020

(c) Springer-Verlag Italia S.r.l., part of Springer Nature 2020

The coronavirus disease (COVID-19) pandemic has caused an unprecedented lockdown worldwide, resulting in social isolation due to the guidance for people to stay at home in quarantine to prevent the spread of this infectious disease [1]. However, this control measure has several impacts on society, such as on psychological health, relationships, education, business, employment, and leisure time.

Evidence shows that longer durations of quarantine are associated with poorer mental health, specifically posttraumatic stress symptoms [2]. The duration of quarantine is a stress factor, and people who have stayed in quarantine for more than 10 days have shown significantly higher post-traumatic stress symptoms than those in quarantine for fewer than 10 days [2]. During the COVID-19 pandemic, symptoms of anxiety were verified in college students in China and in the Indian population, which could be caused by social distancing $[3,4]$.

In a recent analysis of human needs in COVID-19 isolation, Matias, Dominski and Marks (2020) [5] showed several conditions emphasized by social distancing, such as satisfying immediate physiological needs, and the need for selfprotection, affiliation and status/self-esteem; hence, there are negative mental health consequences, such as fear, anxiety and distress, and people are more vulnerable to depression due to low self-esteem [5]. This is evident in some fragile populations: in addition to being within the at-risk/vulnerable group, older adults may be adversely affected by the discourses that imply that the loss of older life is not as

Fábio Hech Dominski

fabio.dominski@udesc.br

1 Laboratory of Sport and Exercise Psychology, College of Health and Sport Science of the Santa Catarina State University, Florianopolis 88080-350, Brazil

2 Physical Education Department, Western Parana State University, Marechal Cândido Rondon, Cascavel, Brazil

3 Univille University, Paulo Malschitzki, 10 - Zona Industrial Norte, Joinville, SC, Brazil important as the loss of life of younger people [6], for example, when health systems worldwide need to decide who should be prioritized for treatment of COVID-19.

Although research on the consequences of the COVID19 pandemic on physical inactivity is at an initial stage [7], it is expected that people in quarantine at home could increase their sedentary behaviour through more screen time, characterized by the time watching television, using mobile devices, and playing games, thereby reducing physical activity levels. Physical inactivity is a huge public health issue and approximately one in three adults and four in five adolescents, worldwide, do not achieve the recommended quantity and quality of physical activity [8-10], and this issue can be potentiated as a function of COVID-19. There is a current concern about the effects of physical inactivity on the general population and notably on at-risk/vulnerable groups for severe illness from COVID-19, such as older adults, people with cardiovascular disease and rheumatic diseases [11-16]. The reduction in physical activity worsens the risks to these populations since there is an increasing risk factor burden.

Social distancing implies negative consequences that are already happening; however, we need to discuss ways to mitigate these issues. There is a strong recommendation for people to stay active during this critical period to maintain physical and mental health $[17,18]$. In light of public health recommendations, physical activity is on the table. Thus, this work aimed to discuss the counterbalance between the benefits of physical activity and the current infection risks of performing exercise in different environments.

People should be advised of the need to perform regular physical activity due to two major points related to the fundamental role of physical activity: mental health and the immune system. Significant evidence shows that physical activity enhances the immune system $[19,20]$ as well as psychological well-being [21, 22], and anti-inflammatory effects [23]. Next we expose the positive potential role of exercise that should be considered, especially in times of pandemic. 
Physical activity has a positive effect on immune competence, increasing the host immune defences [19, 20, 24]. It is recognized that active people are less likely to present symptoms of upper respiratory (a vulnerable area to infections) illness [24, 25]. In recent analysis of a holistic immunological model of COVID-19, Matricardi, Negro, and Nisini (2020) [26] highlighted the opposite impact of low-moderate versus strenuous exercise, in which low-moderate exercise has benefits for the innate immune response against respiratory infections, in contrast to strenuous exercise, in which there is a tremendous increase of alveolar ventilation and susceptibility to upper respiratory airways infection [26].

Matias, Dominski, and Marks (2020) [5] provided the rationale to understand the relationship between physical activity at home and mental health during the COVID19 pandemic and showed that increased physical activity enables a reset of physical and mental well-being. At this time, bouts of exercise are fundamental in the means of distracting individuals from worrying and negative thoughts, evidenced by the pandemic [5]. A daily exercise routine is important to offer pleasant situations at some moment in the day. Furthermore, exercise might be accompanied by higher self-esteem, and a satisfying of basic psychological needs [5].

Strength, flexibility and stability training can have a positive impact on physiological domains (hormonally, neurologically, metabolically, and behaviourally); therefore, they are both a viable and potent adjunct to any physical activity prescription for adults, and can be considered parameters associated with physical fitness and health [27, 28]. Lee et al. (2017) [29] proposed a review surrounding the impact of running on health outcomes and premature mortality, highlighting plausible underlying mechanisms linking running with chronic disease prevention and longevity. Skeletal muscle is known to be a very adaptable tissue that atrophies during conditions of unloading, such as bed rest, and hypertrophies in response to resistance exercise [30]. Regular physical activity helps reduce several cardiovascular risk factors, including obesity, dyslipidaemia, metabolic syndrome, among others [31].

Sleep is another aspect of people's lives and health affected by the COVID-19 pandemic. Initial research showed that the sleep quality of isolated individuals during the COVID-19 outbreak in China was low [32, 33]. Evidence supports that exercise improves sleep quality in middle-aged and older adults [34].

Recent evidence showed that enhanced aerobic capacity could protect against COVID-19 through improving specific immunity elements (especially if the exercise requires mainly the cardiorespiratory system, which mobilizes billions of lymphocytes) [24], and may decrease the severity of the disease [35]. Therefore, in addition to age and clinical criteria, the maximal oxygen uptake $\left(\mathrm{VO}_{2} \max \right)$ has the potential to be used as a clinically relevant triage tool [36].

Knowing that exercise could become a key pillar for health recovery and COVID-19 prevention, it is important to keep following the physical activity guidelines for adults and older adults - 150-300 min of moderate- to vigorousintensity cardiorespiratory physical activity and two sessions of muscle strength training, per week [37, 38]. Considering the need to maintain a healthy lifestyle with regular physical activity, associated to the public health guidelines about what people can do or avoid regarding physical activity through exercise, considering the risks related to the environments to perform this activity, the question to be discussed is: What are the implications of exercise in indoor and outdoor environments during the COVID-19 pandemic? Public health messages are necessary and should be careful, clear, evidence-based, and transparent during the pandemic; this editorial also aims to address this issue.

Considering that COVID-19 is spread by human-tohuman transmission via droplets [39, 40], in several countries, as a control measure to prevent the spread of COVID19 , a social distance of about $1.5 \mathrm{~m}$ between individuals was adopted [41, 42]. However, research has indicated that the virus can be detected-but not necessarily capable of infecting-within $4 \mathrm{~m}$ of patients with COVID-19 in hospital wards in Wuhan, China [43]. Besides, infection spread by direct contact, the airborne transmission of SARS-CoV-2, should be considered, especially in indoor environments [44, 45]. Small particles ( $<5 \mathrm{~mm})$, known as aerosols, can result in airborne transmission potentially over longer distances because these particles can remain suspended in the air for prolonged periods $[45,46]$, especially the smaller droplets that can travel tens of meters [44].

In preprint research, Blocken et al. [47] discussed that the distance of $1.5 \mathrm{~m}$ may be sufficient when people are standing still and only if everybody wears face masks [45]; however, there is a need to know if it is different when people walk, run, or cycle. In this sense, through computational fluid dynamics simulations, the authors considered different configurations of walkers/runners according to distance and positions among them, and the worst scenario was when the trailing runner is positioned in the slipstream of the leading runner, resulting in the largest exposure to droplets [47]. The distance among runners and the traveling speed are important factors, due to the exposure to a larger fraction of droplets; thus, the authors recommended a distance of about $5 \mathrm{~m}$ and $10 \mathrm{~m}$ for walking fast and running, respectively [47]. The World Health Organization (2020) [17] recommends that if people go to a park or open public space to walk, run, or exercise, there is a need to always practice physical distancing. While the safe distance is still discussed in science, care is needed in the interpretation of these preliminary and non-published results, and it is important to 
analyze influencing factors in further studies, such as the head position of the practitioners during exercise, as well as the direction and speed of the wind.

Although there is no study on cycling, even with small groups of cyclists, if there is a potential symptomatic carrier in front of the group, this individual could cause droplet transfer to the others (slipstream of the leading person). This issue could be worse than walking or running due to the traveling speed during cycling, which requires more distance between the cyclists. It is no small matter, as the risk of accident is intrinsic to cycling. Falls, for example, are a serious issue for cyclists. In this context, the recommendation for outdoor activities may need to be carefully evaluated, because hospital beds must be prioritized for patients with COVID-19.

The literature suggests that indoor environments have the greatest risk of infection, due to the larger density of people, the possible buildup of airborne virus-carrying droplets, and the likely higher stability of the virus in indoor air [44, 45]. The risk of infection for individuals exercising indoors increases during the peak of occupancy when the ventilation required by those training is greater [48]. Thus, indoor exercise in places with a higher number of people is an activity with a high risk of infection at this moment and should be avoided. Furthermore, human coronaviruses can remain infectious on inanimate surfaces for up to 9 days and in the air for up to 5 hours $[49,50]$.

In a recent analysis during 24 days at 12 sports facilities in Cheonan, South Korea, Jang, Han, and Rhee (2020) [51] identified 112 persons infected with COVID-19 associated with fitness dance classes. The large class sizes, small spaces, and intensity of the workouts were factors that influenced the infections [51]. In gyms, a common place to exercise worldwide, inefficient ventilation could be a significant problem, resulting in an increased risk of infections [48, 52]. In an editorial discussing whether exercise should be performed, Halabchi et al. (2020) [53] call attention to highintensity exercise in public gyms and crowded environments, in which, in these conditions, the hazards may outweigh the benefits.

Most people can feel physical and mental benefits from exercise,; however, this practice needs to be performed safely and appropriately [5]. In this sense, setting specific standards of exercise practice regarding safety and hygiene protocols and procedures to avoid failing social distance during training sessions is required. Besides the general recommendations, guidelines and orientations specific to exercise environments are available in the literature, as well as from institutions and governments worldwide [26, 44, 45, 54-59] and are shown in Table 1.

Besides the safety and hygiene protocols, an appropriate exercise prescription, based on an individual assessment of health status and fitness levels, is more necessary than ever. Initially, in environments and facilities such as gyms and fitness centers, there is a need for better screening for exercise. In this sense, Neto et al. (2020) [60] developed the Pre-Exercise Screening Questionnaire (PESQ), which assesses in an easy, simple and quick way whether people are in a suitable place to start exercising during the COVID-19 pandemic through questions related to symptoms of COVID-19. From now on, this instrument could be applied on a large scale with low implementation costs.

It is important to highlight that relevant physiological changes occur during exercise, such as increased ventilation demand and respiratory frequency (from 15 to 20 up to 50 breaths per min), enhanced volume of exhaled air and airflow velocity, and inhalation of air through the mouth rather than through nasal filtering mechanisms [61-63]; these changes vary according to exercise intensity. These are important factors that should be considered in this analysis for both indoor and outdoor exercise. In this sense, exercise stress is associated with an increased risk of upper respiratory tract infection. In the meantime, moderate exercise has been associated with a decreased risk. There is a growing body of evidence showing that severe exercise can increase susceptibility to upper respiratory tract infection [64].

Therefore, the guidance based on research and official guidelines is to avoid exercise in indoor environments with higher occupancy, and if performing outdoor exercise (walking, running, or cycling), there is a need to keep larger social distances or adopt a side-by-side arrangement. In summary, the benefits of exercise during the COVID-19 pandemic may outweigh the risks of infection; however, caution is needed in both indoor-where contamination could be airborne and through touching potentially contaminated materials-and outdoor environments. Exercise should be as promoted as social isolation [5]. We strongly recommended that people stay active with regular exercise.

The present analysis promotes a critical appraisal that is relevant to help people to stay active while preventing the spread of the disease, thus avoiding additional cases of infection in the near future by individuals who are exercising to maintain health but could be at risk of infection, which is a contrast to the fact that individuals exercise for better health. The summary of guidelines and orientations related to social distancing, safety and hygiene applied to exercise environments, based on research and official institutions, has useful practical applications and may collaborate with the implementation of public health strategies both during the pandemic and in the post-pandemic period. 
Table 1 Guidelines and orientations related to social distancing, safety and hygiene when exercising in indoor and outdoor environments, according to the environment and place

\begin{tabular}{|c|c|c|c|}
\hline Guideline related to & Orientation & Environment & Place \\
\hline \multirow[t]{4}{*}{ Social distancing } & $\begin{array}{l}\text { Exercise as long as you follow social distancing guidelines-at least } 2 \mathrm{~m} / 6 \\
\text { feet apart (if there is use of face masks) but "further is safer" }\end{array}$ & Outdoor & Parks or open public space \\
\hline & $\begin{array}{l}\text { When face masks are not used more extensive distancing measures (up to } \\
10 \mathrm{~m} \text { of distance among persons) should be adopted in indoor environments }\end{array}$ & Indoor & Gyms and fitness centers \\
\hline & $\begin{array}{l}\text { Implement protective measures as wearing masks and daily health checks for } \\
\text { symptoms }\end{array}$ & Indoor & \\
\hline & Avoid physical activities that involve body contact, such as team sports & Indoor/outdoor & Sporting courts and fields \\
\hline \multirow[t]{6}{*}{ Safety } & $\begin{array}{l}\text { Limit the number of people in the facility at one time, typically vary between } \\
10 \mathrm{~m}^{2} \text { and } 15 \mathrm{~m}^{2} \text { per person }\end{array}$ & Indoor & Gyms and fitness centers \\
\hline & Prefer moments in which there is little flow of people in exercise facilities & Indoor/outdoor & All \\
\hline & $\begin{array}{l}\text { Limit the time people spend exercising in the indoor environment to decrease } \\
\text { exposure time }\end{array}$ & Indoor & Gyms and fitness centers \\
\hline & Avoid the use of cellphone during exercise in shared environments & Indoor & \\
\hline & $\begin{array}{l}\text { Using natural ventilation, increasing the ventilation rate, avoiding air recir- } \\
\text { culation, and guiding people to avoid staying in another person's direct air } \\
\text { flow in indoor environments }\end{array}$ & Indoor & \\
\hline & Prefer low-moderate intensity exercises rather than strenuous exercise & Indoor/outdoor & All \\
\hline \multirow[t]{4}{*}{ Hygiene } & Avoid the sharing of bottles & Indoor/outdoor & All \\
\hline & $\begin{array}{l}\text { The need for hand-washing or hand-sanitizer stations with easily accessible } \\
\text { in facilities }\end{array}$ & Indoor & Gyms and fitness centers \\
\hline & $\begin{array}{l}\text { Sanitize exercise equipment's regularly (before and after using the equip- } \\
\text { ment), not only weight machines but also bands, hand weights, foam roll- } \\
\text { ers, yoga blocks, mats and towels }\end{array}$ & Indoor & \\
\hline & $\begin{array}{l}\text { Cleaning, ventilation, and disinfection processes are required in group exer- } \\
\text { cise spaces by at least a } 10-15 \text { min space between classes }\end{array}$ & Indoor & \\
\hline
\end{tabular}

\section{Compliance with ethical standards}

Conflict of interest The authors declare that they have no conflict of interest.

Ethical approval Not applicable.

Informed consent Not applicable.

\section{References}

1. Kraemer MU, Yang C-H, Gutierrez B, Wu C-H, Klein B, Pigott DM et al (2020) The effect of human mobility and control measures on the COVID-19 epidemic in China. Science 368(6490):493-497. https://doi.org/10.1126/science.abb4218

2. Brooks SK, Webster RK, Smith LE, Woodland L, Wessely S, Greenberg N, Rubin GJ (2020) The Psychological impact of quarantine and how to reduce it: rapid review of the evidence. Lancet 395:912-920

3. Cao W, Fang Z, Hou G, Han M, Xu X, Dong J, Zheng J (2020) The psychological impact of the COVID-19 epidemic on college students in China. Psychiatry Res 287:112934

4. Roy D, Tripathy S, Kar SK, Sharma N, Verma SK, Kaushal V (2020) Study of knowledge, attitude, anxiety and perceived mental healthcare need in Indian population during COVID-19 pandemic. Asian J Psychiatry 51:102083
5. Matias TS, Dominski FH, Marks D (2020) Human needs in COVID-19 isolation. J Health Psychol. https://doi. org/10.1177/1359105320925149

6. Brooke J, Jackson D (2020) Older people and COVID-19: Isolation, risk and ageism. J Clin Nurs. https://doi.org/10.1111/ jocn.15274 (Online ahead of print)

7. Sekulic D, Blazevic M, Gilic B, Kvesic I, Zenic N (2020) Prospective analysis of levels and correlates of physical activity during COVID-19 pandemic and imposed rules of social distancing; gender specific study among adolescents from southern Croatia. Sustainability 12:4072

8. Guthold R, Stevens GA, Riley LM, Bull FC (2018) Worldwide trends in insufficient physical activity from 2001 to 2016: a pooled analysis of 358 population-based surveys with 1.9 million participants. Lancet Glob Health 6(10):e1077-e1086

9. Guthold R, Stevens GA, Riley LM, Bull FC (2020) Global trends in insufficient physical activity among adolescents: a pooled analysis of 298 population-based surveys with 16 million participants. Lancet Child Adolesc Health 4(1):23-35

10. Hallal PC, Andersen LB, Bull FC, Guthold R, Haskell W, Ekelund U (2012) Physical activity series working group. Global physical activity levels: surveillance progress, pitfalls, and prospects. Lancet 380:247-257

11. Aubertin-Leheudre M, Rolland Y (2020) The importance of physical activity to care for frail older adults during the COVID-19 pandemic. J Am Med Dir Assoc. https://doi.org/10.1016/j.jamda .2020.04.022

12. Burtscher J, Burtscher M, Millet GP (2020) (Indoor) isolation, stress and physical inactivity: vicious circles accelerated by 
Covid-19? Scand J Med Sci Sports. https://doi.org/10.1111/ sms.13706 (Online ahead of print)

13. Hall G, Laddu DR, Phillips SA, Lavie CJ, Arena R (2020) A tale of two pandemics: how will COVID-19 and global trends in physical inactivity and sedentary behavior affect one another? Prog Cardiovasc Dis. https://doi.org/10.1016/j. pcad.2020.04.005 (Online ahead of print)

14. Lippi G, Henry BM, Sanchis-Gomar F (2020) Physical inactivity and cardiovascular disease at the time of coronavirus disease 2019 (COVID-19). Eur J Prev Cardiol 27(9):906-908

15. Pinto AJ, Dunstan DW, Owen N, Bonfá E, Gualano B (2020) Combating physical inactivity during the COVID-19 pandemic. Nat Rev Rheumatol 16:347-348

16. Roschel H, Artioli GG, Gualano B (2020) Risk of increased physical inactivity during COVID-19 outbreak in elderly people: a call for actions. J Am Geriatr Soc. https://doi.org/10.1111/ jgs. 16550 (Online ahead of print)

17. World Health Organization Europe (2020) Stay physically active during self-quarantine. http://www.euro.who.int/en/health-topic s/health-emergencies/coronavirus-covid-19/novel-coronaviru s-2019-ncov-technical-guidance/stay-physically-active-durin g-self-quarantine. Accessed 3 Apr 2020

18. Chen P, Mao L, Nassis GP, Harmer P, Ainsworth BE, Li F (2020) Wuhan coronavirus (2019-nCoV): the need to maintain regular physical activity while taking precautions. J Sport Health Sci 9:103

19. Simpson RJ, Campbell JP, Gleeson M, Krüger K, Nieman DC, Pyne DB, et al (2020) Can exercise affect immune function to increase susceptibility to infection? Exerc Immunol Rev 26:8-22

20. Campbell JP, Turner JE (2018) Debunking the myth of exerciseinduced immune suppression: redefining the impact of exercise on immunological health across the lifespan. Front Immunol 9:648

21. Chekroud SR, Gueorguieva R, Zheutlin AB, Paulus M, Krumholz HM, Krystal JH, Chekroud AM (2018) Association between physical exercise and mental health in 1.2 million individuals in the USA between 2011 and 2015: a cross-sectional study. Lancet Psychiatry 5(9):739-746

22. Mikkelsen K, Stojanovska L, Polenakovic M, Bosevski M, Apostolopoulos V (2017) Exercise and mental health. Maturitas 106:48-56

23. Metsios GS, Moe RH, Kitas GD (2020) Exercise and inflammation. Best Pract Res Clin Rheumatol. https://doi.org/10.1016/j. berh.2020.101504 (Ahead of print)

24. Simpson RJ, Katsanis E (2020) The immunological case for staying active during the COVID-19 pandemic. Brain Behav Immun. https://doi.org/10.1016/j.bbi.2020.04.041

25. Duggal NA, Niemiro G, Harridge SDR, Simpson RJ, Lord JM (2019) Can physical activity ameliorate immunosenescence and thereby reduce age-related multi-morbidity? Nat Rev Immunol 19:563-572

26. Matricardi PM, Dal Negro RW, Nisini R (2020) The first, holistic immunological model of COVID-19: implications for prevention, diagnosis, and public health measures. Pediatr Allergy Immunol. https://doi.org/10.1111/pai.13271 (Online ahead of print)

27. Micheo W, Baerga L, Miranda G (2012) Basic principles regarding strengh, flexibility and stability exercises. PM\&R 4(1):805-811

28. Seguin R, Nelson ME (2003) The benefits of strength training for older adults. Am J Prev Med 25(3):141-149

29. Lee D, Brellenthin AG, Thompson PD, Sui X, Lee I, Lavie CJ (2017) Running as a key lifestyle medicine for longevity. Prog Cardiovasc Dis 60(1):45-55

30. Fitts RH (2003) Effects of regular exercise training on skeletal muscle contractile function. Am J Phys Med Rehabil 82:320-331

31. Agaral SK (2012) Cardiovascular benefits of exercise. Int J Gen Med 5:541-545
32. Xiao H, Zhang Y, Kong D, Li S, Yang N (2020) Social capital and sleep quality in individuals who self-isolated for 14 days during the coronavirus disease 2019 (COVID-19) outbreak in January 2020 in China. Med Sci Monit 26:e923921-e923931

33. Liu K, Chen Y, Wu D, Lin R, Wang Z, Pan L (2020) Effects of progressive muscle relaxation on anxiety and sleep quality in patients with COVID-19. Complement Ther Clin Pract 39:101132

34. Yang PY, Ho KH, Chen HC et al (2012) Exercise training improves sleep quality in middle-aged and older adults with sleep problems: a systematic review. J Physiother 58(3):157-163

35. Mohamed A, Alawna M (2020) Role of increasing the aerobic capacity on improving the function of immune and respiratory systems in patients with coronavirus (COVID-19): a review. Diabetes Metab Syndr 14(4):489-496. https://doi.org/10.1016/j. dsx.2020.04.038

36. Ahmed I (2020) COVID-19: does exercise prescription and maximal oxygen uptake (VO2 max) have a role in risk-stratifying patients? Clin Med 20(3):282-284. https://doi.org/10.7861/clinm ed.2020-0111

37. Piercy KL, Troiano RP, Ballard RM, Carlson SA, Fulton JE, Galuska DA, George SM (2018) Olson RD. Phys Act Guidel Am Jama 320:2020-2202

38. World Health Organization (2010) Global recommendations on physical activity for health. https://apps.who.int/iris/bitstream/ handle/10665/44399/9789241599979_eng.pdf?sequence $=1$. Accessed 4 Apr 2020

39. Lai CC, Shih TP, Ko WC, Tang HJ, Hsueh PR (2020) Severe acute respiratory syndrome coronavirus 2 (SARS-CoV-2) and coronavirus disease-2019 (COVID-19): the epidemic and the challenges. Int J Antimicrob Agents 55(3):105924

40. Yuen KS, Ye ZW, Fung SY, Chan CP, Jin DY (2020) SARSCoV-2 and COVID-19: the most important research questions. Cell Biosci 10(1):1-5

41. Australian Government (2020) Keeping your distance. https:// www.health.gov.au/sites/default/files/documents/2020/03/coron avirus-covid-19-keeping-your-distance.pdf. Accessed 4 Apr 2020

42. Lazzerini M, Putoto G (2020) COVID-19 in Italy: momentous decisions and many uncertainties. Lancet Glob Health. https:// doi.org/10.1016/S2214-109X(20)30110-8

43. Guo ZD, Wang ZY, Zhang SF, Li X, Li L, Li C, Zhang MY (2020) Early release-aerosol and surface distribution of severe acute respiratory syndrome coronavirus 2 in hospital wards, Wuhan, China, 2020. Emerg Infect Dis. https://doi.org/10.3201/eid2607.200885

44. Morawska L (2020) Cao J (2020) Airborne transmission of SARS-CoV-2: the world should face the reality. Environm Int 139: 105730

45. Setti L, Passarini F, Gennaro GD, Barbieri P, Perrone MG, Borelli M, Miani A (2020) Airborne transmission route of COVID19: why 2 meters/ 6 feet of inter-personal distance could not be enough. Int J Environ Res Public Health 17(8):2932. https://doi. org/10.3390/ijerph17082932

46. Seto WH (2015) Airbone transmission and precautions: facts and myths. J Hosp Infect 89:225-228

47. Blocken et al. (2020) Towards aerodynamically equivalent COVID19 $1.5 \mathrm{~m}$ social distancing for walking and running. Preprint. https://www.urbanphysics.net/Social\%2520Distan cing\%2520v20_White_Paper.pdf. Accessed 15 Apr 2020

48. Andrade A, Dominski FH, Pereira ML, de Liz CM, Buonanno G (2018) Infection risk in gyms during physical exercise. Environ Sci Pollut Res 25(20):19675-19686

49. Kampf G, Todt D, Pfaender S, Steinmann E (2020) Persistence of coronaviruses on inanimate surfaces and their inactivation with biocidal agents. J Hosp Infect 104:246-251

50. Doremalen NVD, BUshmaker T, Morris DH, Holbrook MG, Gamble A, Williamson BN, Tamin A, Harcourt JL, Thornburg NJ, Gerber SI, Lloyd-Smith JO, Wit E, Munster VJ (2020) Aerosol 
and surface stability of SARS-CoV-2 as compared with SARSCoV-1. N Engl J Med 382:1564-1567. https://doi.org/10.1056/ NEJMc2004973

51. Jang S, Han SH, Rhee J-Y (2020) Coronavirus disease cluster associated with fitness dance classes, South Korea. Emerg Infect Dis. https://doi.org/10.3201/eid2608.200633

52. Andrade A, Dominski FH (2018) Indoor air quality of environments used for physical exercise and sports practice: systematic review. J Environ Manage 206:577-586

53. Halabchi F, Ahmadinejad Z, Selk-Ghaffari M (2020) COVID-19 epidemic: exercise or not to exercise; that is the question! Asian J Sports Med 11(1):e102630

54. Chen P, Mao L, Nassis GP, Harmer P, Ainsworth B, Li F (2020) Returning Chinese school-aged children and adolescents to physical activity in the wake of COVID-19: actions and precautions. J Sport Health Sci. https://doi.org/10.1016/j.jshs.2020.04.003 (Epub ahead of print)

55. Eirale C, Bisciotti G, Corsini A, Baudot C, Saillant G, Chalabi H (2020) Medical recommendations for home-confined footballers' training during the COVID-19 pandemic: from evidence to practical application. Biol Sport 37(2):203-207

56. GOV.UK (2020) Guidance. Coronavirus outbreak FAQs: what you can and can't do. https://www.gov.uk/government/publicatio ns/coronavirus-outbreak-faqs-what-you-can-and-cant-do/coron avirus-outbreak-faqs-what-you-can-and-cant-do. Accessed 15 Apr 2020

57. EuropeActive, the European Health and Fitness Association (EHFA) (2020) Summary of current recommended practices for operating under COVID-19 restrictions. https://www.europ
eactive.eu/sites/europeactive.eu/files/covid19/Operating_Pract ices_May2020.pdf. Accessed 15 Apr 2020

58. IHRSA (2020) Coronavirus Resources for Health Clubs-18 Safety Considerations for Your Health Club Reopening Plan. https://www.ihrsa.org/improve-your-club/safety-considerationsfor-your-health-club-reopening-plan/\#. Accessed 15 Apr 2020

59. TN.GOV (2020) Exercise Facilities. https://www.tn.gov/content/ dam/tn/governorsoffice-documents/covid-19-assets/Pledge_Exerc ise.pdf. Accessed 15 Apr 2020

60. Neto LO, de Oliveira Tavares VD, Schuch FB, Lima KC (2020) Coronavirus pandemic (SARS-COV-2): pre-exercise screening questionnaire (PESQ) for telepresential exercise. Front Public Health 8:146. https://doi.org/10.3389/fpubh.2020.00146

61. Carlisle AJ, Sharp NCC (2001) Exercise and outdoor ambient air pollution. Br J Sports Med 35(4):214-222

62. McKenzie DC (2012) Respiratory physiology: adaptations to high-level exercise. Br J Sports Med 46(6):381-384

63. Aliverti A (2016) The respiratory muscles during exercise. Breathe 12(2):165-168

64. Murphy EA, Davis JM, Carmichael MD, Gangemi JD, Ghaffar A, Mayer EP (2008) Exercise stress increases susceptibility to influenza infection. Brain Behav Immun 22:1152-1155

Publisher's Note Springer Nature remains neutral with regard to jurisdictional claims in published maps and institutional affiliations. 